\title{
Interactive comment on "Annual cycle of water vapour in the lower stratosphere over the Indian Peninsula derived from Cryogenic Frost-point Hygrometer observations" by Maria Emmanuel et
}

al.

Maria Emmanuel et al.

sunilspl@yahoo.co.in

Received and published: 28 November 2018

The response to Reviewer 2 is attached. The response is given in blue colour

Please also note the supplement to this comment:

https://www.atmos-chem-phys-discuss.net/acp-2018-630/acp-2018-630-AC2- 
2018.

ACPD

Interactive

comment

Printer-friendly version

Discussion paper 